\title{
Pneumatic Episodes from Homer to Galen
}

\author{
A. A. Long
}

\section{INTRODUCTION}

Ancient Greece is an apt time and place for the start of this book's explorations of the life of breath. Greek breath (pneuma) was all around, in the guise of wind or air; it was what Hellenic people inhaled and exhaled every moment; it was the vital spirit ( $p s y c h e$ ) that coursed through their blood vessels; and it was the 'holy spirit' (hagion pneuma) of the New Testament. Our chemistry and physiology have moved on exponentially, but we have inherited the Greeks' pneuma in numerous ways, including language (think of 'pneumonia'), metaphor ('breath of life'), or even giving up the ghost. The 'pneumatic episodes' of this essay start with the earliest texts and contexts of Homeric epic. They then range through salient passages of philosophy and medicine, including Hippocrates' extraordinary essay on epilepsy and a Stoic account of

This essay is largely built around a selection of texts. I am responsible for the translations unless otherwise indicated. For access to the Greek originals I include a selection of editions in the notes and bibliography.
A. A. Long $(\bowtie)$
Classics Department, University of California, Berkeley, CA, USA
(C) The Author(s) 2021
D. Fuller et al. (eds.), The Life of Breath in Literature, Culture
and Medicine, Palgrave Studies in Literature, Science and Medicine, https://doi.org/10.1007/978-3-030-74443-4_2 
embryology. The episodes conclude with Galen's ideas about psychic pneuma, the use of breathing, and the pathologies of breathlessness. These ancient authors explored vital connections between breath, heart, mind (psyche), and brain. They also considered how breath functions to control the body's temperature, how animal life begins with breath, and why breath and breathing are symptomatic for health and sickness. Their ancient thoughts resonate with this book's generic themes, especially breath's significance and importance for our inhabiting and understanding the world.

Greek breath is most familiar to English speakers in our words pneumonia and pneumatic. Respiratory illness and air pressure, conveyed by these words respectively, have breath or wind in common. Unsurprisingly, then, pneuma was a key term for Greek medical writers and also for philosophers engaged with 'physics' or study of nature (physis). The Latin equivalent of pneuma is spiritus, giving us vital spirits and spirituality. The obsolete word 'pneumatology' was coined in the seventeenth century to convey the study of spiritual or divine beings. And in the next century so-called pneumatologists took on the secular subject of the human mind or soul, prefiguring the field that later came to be called psychology. In extending the range of pneuma from respiration and air to topics of theology and psychology our British forebears were as close to ancient Greek usage as when they were speaking in the contexts of medicine or physics. As for the subject of psychology, whose word derives from psyche (commonly rendered by soul or mind), breath or pneuma plays a central role in many Greek speculations concerning the source and make-up of our mental life and faculties.

Greek breath, then, or pneuma, is a notion of enormous scope. We can study its usage in a huge range of different texts and contexts-in poetic and prose authors who describe everyday conditions of body and mind; in technical treatments by medical writers and philosophers; in meteorology and cosmology; and in the word's extension from the strictly physical notions of air, respiratory breath, and vaporous substance transmitted in the blood vessels, to the domain of immaterial (non-physical) reality or spirituality. To cover all of this in a single essay is obviously out of the question. What I can do, to open our volume's vast topic, is present some key episodes and texts in the ancient life of breath as recorded by a selection of Greek authors, starting with Homer and concluding with Galen, a period of almost a millennium. 
We should remember from the outset that Greek authors, like everyone else until two hundred and fifty years ago, knew nothing of oxygen and carbon dioxide. There was much debate and disagreement, therefore, about the nature of breath and the biological function of breathing. Greek philosophers and physicians lacked all chemistry in our sense of the term. Their so-called 'physical' elements were just the hoary quartet, earth, air, fire, and water, with dry, cold, hot, and moist as the corresponding elementary qualities. They had no instruments to measure temperature and air pressure. Their ideas were more imaginative than accurate concerning the cardiovascular system, the pumping function of the heart, and the relationship between blood flow and breathing. They treated cold and hot, especially what they called 'innate heat', as quasi-substances. Yet, in spite of these scientific vagaries, we can still be impressed by the empirical soundness of many Greek findings, their grasp of basic anatomy, and the amazing range of their omnium gatherum concept of pneuma.

\section{Breath AND Life in THE EARLiest GreEk Literature}

Tl Of all that breathe (pneiei) and crawl on the earth, none is more piteous than man.-Homer, Iliad 17, 446-47.

T2 His life (psyche) left Sarpedon, and mist poured over his eyes; but he inhaled again (empnunthe), and a gust (pnoie) of the North Wind blowing around him restored (zogrei) his flagging spirit (thumos).Iliad 5, 696-98.

T3 Zeus saw Hektor sprawled on the battlefield, his comrades kneeling around him; and he had difficulty breathing (argaleo asthmati), losing consciousness in his heart (ker apinusson) and vomiting blood (baima).-Iliad 15, 9-11.

T4 Odysseus digs a trench, to evoke the shades (psychai) of the dead from the underworld. After drinking sacrificial blood, the shades recover their wits and converse with him.-Homer, Odyssey 11, summary of lines 24-50.

T5 [The shade of Antikleia speaks about death to her son Odysseus:] Our sinews no longer grip our flesh and bones, but they are destroyed by the fierce fire as soon as the thumos departs from our white bones, and the psyche flies away like a dream.-Odyssey 11, 219-22.

The Greek noun pneuma in its earliest instances signifies wind or breeze, not inhaled or exhaled breath. But the corresponding verbs pneo and 
empneo, meaning breathe and inhale respectively, occur in two of the Homeric passages cited above (T1, T2). For the extraordinary range of pneuma that I have already outlined the word's primary sense of wind is of paramount importance. What we inhale is something that is ubiquitous on and around the earth, invisible, mobile, varying in temperature and speed, and capable of extreme force. These properties of wind have obvious bearing on the connotations of breath as a (or rather the) vital power in our bodies irrespective of breath's precise role and properties in biology and anatomy. Our life's dependence on breath and breathing puts us into a direct and intrinsic relationship with one of the planet's great powers along with water, solar heat, and light.

In Homer, probably our earliest Greek literary text, a person's sentient life is frequently expressed by the word thumos (which is etymologically related to our word 'fume', as in 'fuming with anger' (T2 and T5). ${ }^{1}$ Within the human body the breathy thumos, vaguely situated in the region of the lungs or diaphragm (phren or phrenes) not the head, is the location and instrument of thoughts and feelings. Homer typically refers to what we call the mind with a hendiadys, saying that some person had such and such a thought or feeling in his or her thumos and phrenes. Loss of thumos (i.e. life breath) signifies loss of consciousness, which results in death if thumos permanently leaves the body. To express that ultimate loss of life breath, Homer has recourse to the word psyche (T4 and T5), meaning vital spirit. For Greek philosophy and medicine, psyche became the standard term not only for the human mind but also for the animating principle of all animals. But in Homer, whose text predates the earliest scientific literature by about two and a half centuries, psyche largely occurs in contexts of dying and of death, much as we used to talk about 'giving up the ghost'. The word's etymology, as the Greeks supposed, draws on two notions, breathe (the verb psycho) and cold (the adjective psychros). Like thumos Homer's psyche constitutes life breath, which we inhale as cold air. Even in thinkers as brilliant and erudite as Aristotle and Galen, this etymology underlay their curious conviction that the primary anatomical purpose of breathing is refrigeration-cooling and regulating the vital heat that flows out from our heart and moves around in our blood vessels.

When the Homeric psyche leaves the body permanently at death, it survives as a mere ghost or shade, a wisp of the spirit that had previously animated the body. To recover any semblance of life sacrificial blood is necessary, as we find Odysseus administering to the vampire-like shades in the book of the dead (T4). While this spooky episode makes for a 
wonderful fairy-tale, the breathy make-up of thumos and psyche together with the draughts of revivifying blood foreshadow medical theories about the vital relationship between respiration and blood. In grasping that crucial connection, Homeric Greeks were already onto one of biology's great truths.

I turn now from breath in Homeric poetry to its role and uses in the earliest Greek scientific literature.

\section{Air/Breath/Wind as Life Force in EArly Greek Philosophy and Medicine}

T6 As our spirit (psyche) being air (aer) controls us, so do wind (pneuma) and air encompass the entire world. - Anaximenes. ${ }^{2}$

T7 The Pythagoreans said that there is a void, and that it enters the universe from the infinite breath (pneuma) as the universe also inhales the void.-Aristotle, Physics 4, $213 \mathrm{~b} 22$.

T8 Pythagoras and Empedocles ... say that we not only have a social relationship (koinonia) with one another and with the gods but also with the non-rational animals. For there is a single breath (pneuma) that permeates the entire universe like a spirit ( $p s y c h e)$, and it unifies us with them.-Sextus Empiricus, Against the Mathematicians Bk 9, $\$ 127$.

T9 Heraclitus (according to the Stoic Zeno) called the vital principle (psyche) a percipient vaporization (aisthetike anathumiasis).Heraclitus. $^{3}$

T10 All creatures including human beings live by inhaling air. It is this that is their spirit (psyche) and intelligence (noesis), and if this is taken away they die and their intelligence fails.-Diogenes of Apollonia. ${ }^{4}$

T11 In my opinion the source of intelligence is what people call air (aer), and everyone is directed by this and it is omnipotent. It is this that I take to be divinity, that reaches to everything and disposes everything and is in everything. ... It is of many kinds, hotter and colder, drier and moister, more stationary and more swiftly mobile. ... In all living creatures the spirit (psyche) is the same, air that is warmer than the air outside in which we exist, but much cooler than the air close to the sun. In none of them is this warmth identical, but different enough for them to be similar. - Diogenes. ${ }^{5}$

T12 Pleasure and pain come about in this way: whenever a lot of air mixes with the blood and reduces its density, in the properly natural way, penetrating right through the body, pleasure comes about. But when the air is present contrary to nature and does not mix, the blood coagulates becoming weaker and denser, and pain is the result... Sentience is due 
to air that is clear and dry; for moisture impedes intelligence. Hence sentience is diminished in sleep and intoxication and over-eating... Plants are completely insentient because they are not hollow and do not take in air...-Diogenes, in Theophrastus, De sensu 39-44. ${ }^{6}$

T13 The bodies of human beings and other animals are nourished by a trio of nutriments; their names are food, drink, and wind (pneuma). Wind in bodies is called breath (phusa) and outside bodies it is called air (aer). This wind is the greatest power of all [as evident in storms on land and sea]. ... For mortals air is the cause of life, and the cause of disease in the sick. So great is the body's need for wind that a person can be deprived of food and drink for several days and survive, but if the windpipe is cut off death will rapidly ensue. Furthermore, all other activities are intermittent, but breathing alone is continuous, by inhalation and exhalation.-Hippocrates, On Breaths 3-4.

The Greeks knew 'air' in the spelling aer. In its earliest uses (from Homer again) aer signifies mist or haze rather than the stuff we inhale. In the 500-400s BCE, when Greek speculation into nature got going in a big way, aer has become atmospheric air, but it retains its early associations with mist and haze from its susceptibility to condensation and rarefaction. Thus the Presocratic philosophers Anaximenes of Miletus and Diogenes of Apollonia pressed air into service as the unitary substance that constitutes everything and causes natural processes by its inherent capacity to change in density and temperature. ${ }^{8}$ Most germane to our theme (as we see in T6, T9, T10, and T11) was the recognition of atmospheric air and breath as the explicit source of life or psyche and the extraordinary promotion of air to the role of world-controlling divinity. The Athenian comic poet Aristophanes mocked this air god in his play Clouds, where the chorus is composed of ethereal goddesses. His principal target was the character he called Socrates whose comic adoration of these unlikely divinities was tantamount to the virtual atheism that soon brought the real Socrates a death sentence.

Diogenes' theories were well known in late fifth-century Athens when Socrates was in his maturity. In Diogenes' philosophy air took on the role of global force and animistic power. When appropriately embodied it endowed creatures with sentience, intelligence, feelings, and emotions (T11, T12), thus constituting the main attributes of a mind. Some hundred years later, Stoic philosophers started to exploit the pantheistic and spiritual potentialities of divine pneuma (retrojected anachronistically onto early Greek philosophers in T8). ${ }^{9}$ As we see in T7, breath and 
breathing could be extended from the microcosm or individual person to the macrocosm or the world as such. In this way breath and the process of breathing offered themselves as models for understanding cosmology while also serving as the basis for biology and sentient life.

Diogenes' interests in air and breath led him to engage in anatomical investigations of the blood vessels and their function in transmitting breath along with blood (T12). Interplay between breath and blood, and their respective contributions to animal life, soon became a constant theme in Greek medicine and philosophy of biology. ${ }^{10}$ In the early medical text T13 we find breath treated as a nutriment along with food and drink-indeed as the prime nutriment because of the immediate mortality consequent on suffocation and also because of the unceasing continuity of respiration throughout life.

I turn now from early Greek speculations about life, breath, and air to ideas concerning the actual process of breathing, the functions of breath within the body, and the relation of breathing to blood flow.

\section{BREATH, BLOOD, AND RESPIRATION IN EARly Greek Thought}

T14 This is how all things inhale (anapnei) and exhale (ekpnei). There are bloodless tubes in their flesh, stretched all over their bodies, and at the mouths of these tubes the outermost surface of skin is pierced right though with many pores, so that the blood is kept in but an easy path is cut for the air (aither) to pass through. Then, when the thin blood rushes away from there, the bubbling air rushes in with violent surge, and when the blood leaps back, the air is breathed out again.-Empedocles. $^{11}$

T15 Diseases are caused by the condition of the body in the following way. When ... the whole body breathes well and the breath passes through without hindrance, health ensues. For breathing takes place not only through the mouth and nostrils, but also throughout the whole body. When the body does not breathe well, diseases ensue in different ways.-Philistion in Anonymus Londinensis $20 .{ }^{12}$

T16 When a person takes in breath (pneuma) by the mouth or the nostrils, it first goes to the brain, then most of it goes to the belly, though some goes to the lungs and some to the veins. From these parts it spreads into the rest by means of the veins. The amount that goes into the belly has merely a cooling effect, but the air that goes into the lungs and the veins, when it enters the cavities and the brain, causes 
sentience (phronesis) and motion of the limbs. So if phlegm completely cuts off the veins from the air, the patient becomes speechless and loses consciousness. ... When the air is shut off in the limbs, and cannot pass through to the outside because of phlegm, the patient kicks; the air, rushing back and forth through the blood, causes convulsion and pain; hence the kicking. These sufferings occur when the phlegm flows cold into the blood which is warm, causing it to chill and stop moving. If the flow of phlegm is extensive and dense, it kills the patient at once; for it takes hold of the blood by its chill and congeals it. If it is not so great, it takes hold at first and blocks respiration; but when it disperses through the veins and mixes with the copious and warm blood, if it loses power in this way, the veins let the air in and consciousness returns.Hippocrates, On the Sacred Disease 10.13

T17 As the breath is being discharged, the area of the chest and the lungs fills up again with the air that surrounds the body, air that goes through the cycle of displacement and penetrates the porous flesh. And again, when the air is turned back and passes outward through the body, it comes round to push respiration inward by way of the mouth and nostrils. ... As the oscillation goes on, the heat of the body pumps digested food from the belly and packs it into the veins. This is the mechanism by which the streams of nourishment continue to flow throughout the bodies of all living beings.-Plato, Timaeus 79c, 80d (trans. by Donald Zeyl, slightly modified). ${ }^{14}$

Veins and arteries (which were not systematically distinguished from one another at this date) were regarded as channels for the motion of breath as well as blood. That notion persisted right down to the time of Galen for whom the vital pneuma manufactured by the heart was transmitted throughout the body via the blood vessels. Rather than regarding the heart as a pump, Empedocles (T14) and Hippocrates (T16) assigned the cause of blood flow to breath and breathing. According to the physician Philistion (T15) breathing takes place not only through the nose and mouth but also through the pores of the skin. ${ }^{15}$ Skin-breathing seems to be implicit in the passages from Empedocles and Hippocrates as well, and to be central to their claims about how breath activates the blood. The main subject of T16 is epilepsy, which Hippocrates, the attributed author, held to be no more 'sacred' than any other illness. Among many notable features of this passage, I draw particular attention to four points: 
1. The cooling function of breath and breathing in general (which will be strongly defended, by both Aristotle and Galen).

2 . The brain as the special destination of inhaled breath.

3. The causal connection between brain, breath, and sentience or consciousness (phronesis).

4. The necessity to normal health of regular respiration and blood flow, which are interrupted by epileptic attacks.

In opting for the brain rather than the heart as the centre of consciousness, the Hippocratic author was way ahead of the time, approximately 400 BCE. ${ }^{16}$ Until the nervous system was discovered in the Hellenistic era, the heart held sway over the brain as the location of mind and emotion. ${ }^{17}$ The Hippocratic author of T16 was also distinctive in making no mention of psyche in this account of breath and the contribution of breath to vital processes. In modern terms he or she looks like a brain/mind identity theorist, who sees no need to specify a special substance or soul, something other than the brain or additional to the brain, as the vital core of conscious and intelligent living.

This silence concerning psyche is most noteworthy. In earlier texts, as we have seen, psyche is embodied in the life breath that we inhale, making it something physical and tangible. The word thus became the standard name for spirit or 'vital principle' (T9-11). In this usage psyche signified a special kind of thing within the body constitutive of both life and mind. By the time of the authors presented in T14-17, psyche could also signify a self or person or soul-a human being viewed from the perspective of character and ethical identity as distinct from body and biological process. Psyche as vital breath - the stuff of respiration-looks straightforwardly physical and empirical. Yet if, as Homeric Greeks had supposed, we are survived after death by a disembodied psyche that is a wraith of our lived self, can vital breath be all that there is to living human beings? Perhaps breath and breathing, though necessary to our embodied life, are merely contingent to our true identity as souls or as mental and moral beings?

Plato was the Greek philosopher who most sharply distinguished psyche as the life of the mind from biological processes. In his late work Timaeus (excerpted in T17) Plato made a significant contribution to the contemporary interests in respiration, blood flow, nutrition, and vital heat. But even there he took little interest in the life of breath as such. What chiefly interested him throughout his copious writings were moral philosophy and philosophy of mind, not physiology and biology. Thus he elaborated 
the notion that what we are, essentially, is an incorporeal and immortal psyche, capable of inhabiting a sequence of bodies, both human and nonhuman. ${ }^{18}$ In this conception, breathing is simply one of many physical processes that incarnate souls activate and experience during their temporary attachment to a particular body. The psyche itself is not a physical being and therefore has no more to do with breath than it has to any other material substance.

Plato's extraordinary dualism became influential only in late antiquity. I mention it here because even hardline materialists such as Plato's near contemporaries, Democritus and Epicurus, found it appropriate to draw a distinction between 'body' and 'soul' in thinking about our biological make-up. Epicurus composed the psyche from atoms (microscopic bodies) compounded in 'a blend of breath (pneuma), heat and a third still more refined constituent'; these especially mobile atoms were proposed to penetrate all parts of the body, much in the way that our nerves actually do, and with comparable functions of transmitting sensations and activating movement. ${ }^{19}$

Does the pneuma of the Hippocratic author (T16) foreshadow the role that Aristotle, Stoic philosophers, and Galen will attribute to 'congenital breath' (symphyton pneuma) as the all-encompassing life force manufactured in the body's blood vessels? ${ }^{20}$ Like the ether once imagined to fill outer space, 'congenital breath' had few scientific credentials from a strictly empirical perspective; but there is nothing mysterious or magical or spiritual about the pneuma that 'causes awareness and motion of the limbs' according to the Hippocratic author of T16. This pneuma is simply the breath of respiration, and the thrust of the passage is entirely empirical. It would be interesting to know how the author would have modified these theories if he or she had known about the nervous system and the circulation of the blood.

Thus far I have illustrated roles assigned to breath and breathing in early Greek treatments of life's vital processes, including health and sickness, thought and feeling, loss of consciousness, and death. ${ }^{21}$ We may also wonder how breath pertains, if it does pertain, to the beginning of life. Death as expiration is self-evident. Pregnancy, on the other hand, is not an outcome of inhalation. How does life get transmitted, and was breath credited with a function in the process of sexual reproduction?

The earliest Greeks in our record, as we have seen, intuited the connection between breathing, continuity of life, and finally death or ultimate loss of breath. As Greek medicine developed, breath (in the form of the 
warm vaporous substance also called pneuma) acquired the further vital function of fostering the onset of life and collaborating with blood and innate heat, in the body's vital processes.

\section{Breath/pneuma as Life-Generating Substance}

T18 Animals and plants are formed in the earth and in the water because in earth water is present, and in water pneuma is present, and in all pneuma soul-heat (thermotes psychiche) is present, so that in a way all things are full of psyche.-Aristotle, Generation of Animals 3.11. ${ }^{22}$

T19 The semen contains within itself that which causes it to be fertilethe so-called hot substance, which is not fire nor any similar substance, but the pneuma enclosed within the semen or foam-like stuff, and the nature in the pneuma, which is comparable to the element of the stars. ... As to the principle of psyche, one portion is separable from body, and belongs to those creatures that include something divine (the sort of thing called intellect), the other portion is inseparable, fluid and watery, dissolves and evaporates.-Ibid., 2.3.

T20 If the semen falls into the womb at the suitable moment, and if at the same time it is gripped (i.e., conceived) by the receptacle when that is in good health, it no longer stays still as it did hitherto, but is set in motion and begins its own specific activities. Drawing material from the pregnant body, it fashions the embryo in accordance with certain fixed patterns up to the time when it reaches its end and makes its product ready to be born. Yet throughout all this time-I mean the time from conception to birth-it persists as merely a 'growth' (physis), i.e., as a pneuma that has changed from semen and is developing systematically from its beginning to its end. In the first stages the 'growth' is breath of a rather compact kind and considerably distant from psyche. But later, and when it has almost reached the moment of birth, the pneuma becomes refined, since it is fanned by the continuous [labour] exertions], and (so far as quantity is concerned) it is psyche. So when it passes outside, it is adequate for the atmosphere, with the result that it is tempered, as it were, by the external air and changes into psyche. For, just as the pneuma in stones is quickly kindled by a blow on account of its readiness for this change, in the same way the 'growth' of the foetus, once it has become ripe, is ready to change into psyche when it encounters the atmosphere. Thus whatever issues forth from the womb is at once an animal.-Stoic philosopher of about $150 \mathrm{CE}$, Elements of Ethics $1^{23}$ 
Both Aristotle and Stoic philosophers had recourse to breath or pneuma as life-generating substance-not the breath of directly inhaled air that has largely occupied us so far, but pneuma as the special, rarefied, warm, and watery substance of which I was writing just now, 'congenital breath', as Aristotle terms it. Passages T18-20 could prompt discussion for an entire book. I include them here not so much for their own fascinating sake, as to illustrate the conceptual connection supposed to obtain between breath or pneuma as a material substance, qualified by attributes like hot and moist, and psyche as the principle of life.

In T18 Aristotle is treating supposedly spontaneous generation of plants and simple animals. In T19 his focus is on sexual reproduction especially of human beings. What chiefly distinguishes our species from other animal kinds is nous or our capacity to engage in rational thinking. Unlike the five senses, which are functions of bodily organs, Aristotelian nous has no physiological correlate. Hence, as he states in T19, the human psyche requires a 'portion' that 'includes something divine', which is not transmitted directly in the pneuma. This non-material, separable and ethereal entity is a clear gesture in the direction of Platonic dualism. Aristotle's 'divine portion' is not literally pneumatic because it is immaterial, but its metaphysical status may be compared to the Judaeo-Christian idea of Holy Spirit (bagion pneuma).

In the text of Hierocles (T20) the Stoic philosopher gives a remarkable account of animal embryology, from the moment of conception to the moment of birth. Pneuma provides the foetus with physiological continuity and consistency from the first moment of its formation to eventual emergence at birth from the womb. This pneumatic or breathy substance, generated by the interaction of semen and female 'matter', gives the foetus initially the status of a mere 'growth' (physis) or plantlike entity. During the embryological process the foetal pneuma develops from this vegetative stage into a fully formed animal. ${ }^{24}$ Transition from the intra-uterine condition to self-sustaining life is marked and caused by the creature taking its first literal breath. We are to presume that this intake of cold air tempers the warm pneuma of the pre-natal creature. That inhalation transforms the embryological pneuma from being purely nutritive and vegetative into sentient and automotive life. 


\section{Galen ON THE UsE OF BREATHING AND THE Causes of BReathlessness}

To conclude this survey, I turn to Galen, classical antiquity's greatest physician, whose prolific writings include several works on respiration. In the book entitled $O n$ the use of breathing Galen reviews five possibilities: (1) to provide the source of the vital principle (psyche); (2) for nourishment; (3) to cool the innate heat; (4) to nourish and to cool; and (5) to replenish the arteries with vital/psychic pneuma. ${ }^{25}$ The first four possibilities had all been canvassed by earlier figures I have reviewed. For the fifth possibility, regarding psychic pneuma, Galen drew on and contested the theories of the great Alexandrian physician, Erasistratus. ${ }^{26}$ Galen concludes that what we require from inhaled air is not its substance (air as such) but the fourth of his five possibilities, a combination of refrigeration and nutriment:

T21 We breathe for regulation of heat, and secondly to nourish the psychic pneuma. The first function is brought about by both parts of breathing, both inhalation and exhalation. To inhalation belong cooling and fanning, and to exhalation, evacuation of the smoky vapour. The second function-nourishment-is brought about by inhalation only-Galen, On the use of breathing $5.8 .^{27}$

At the beginning of this essay I called attention to the ancient Greeks' ignorance of oxygen and carbon dioxide. Yet Galen actually posited an analogue to oxygen in the nutritive function he ascribed to respiration and an analogue to carbon dioxide in the evacuative function of exhalation. As to the mysterious psychic pneuma, Galen showed admirable restraint:

T22 Let us consider ... whether it is possible for the psychic pneuma to draw sustenance from respiration. Let us first say how we give something the name 'psychic pneuma,' ignorant as we confessedly are of the substance of the psyche. Since the emptying of the pneuma from the ventricles in the brain, when it is wounded, at once makes people both motionless and insentient, it must surely be that this pneuma is either the very substance of the psyche or its primary instrument. ... This pneuma must be nourished. From what other source, therefore, will it get nourishment unless from that which is drawn in through inhalation? But it is not improbable that it may be nourished also from the vapour arising from the blood.-Ibid., 5.5. 
This cautious statement, keeping options open, is characteristic of Galen's expository style. Like his contemporary intellectuals and notable predecessors, he continued to invoke a notion of psyche and of psychic pneuma in his accounts of physiology and respiration. But in T22, as elsewhere, he confessed complete uncertainty about the 'substance' of the psyche. ${ }^{28} \mathrm{He}$ showed himself prepared to reduce the psyche to its pneumatic accompaniments whose existence he took to be confirmed by dissection of the brain's ventricles and by the effect of pressure on the unfortunate dissected animal's behaviour. ${ }^{29}$

Because the problem of breathlessness is one of this volume's main themes, I attach an excerpt from Galen's lengthy work entitled On difficulty in breathing. ${ }^{30}$ Its notable features include Galen's focus on the physiological conditions that constrict breathing and increase its speed and 'thickness', and his references to pregnancy, asthma, and cancer. I do not have the medical knowledge to comment on the text in detail, but it may provide a fitting passage to conclude this survey of Greek pneumatic episodes.

T23 Breathing has to increase in speed and density under the following conditions - when the airways contain lumps of undigested food, or are blocked by gluey and thick juices (humours), or some hard excrescence has developed in them, or anything in the adjacent bodies has become excessively elevated for any reason, the breath is inhaled less than it should be on account of the constriction. There are many types of this difficulty in breathing when different parts of the airways are constricted. Irregular growths in the stomach and liver, and also in the spleen and colon and neighbouring parts, by constricting the diaphragm, make breathing weak and rapid and thick. This type of inhalation occurs similarly in people with dropsy or who are pregnant or have eaten too much, or who have a distended belly. In asthmatics (so-called vertical breathers) gluey and thick juices (humours) coagulate in the windpipe. So then, if something hardens there or a lump develops that compresses and narrows the pulmonary passages (arteries), which are the recipients of the incoming air, the breath will be weak and thick and rapid. In the same way, if a lump develops in the chest, as often happens to people who are hunchbacked or bent or crooked in the spine, the breathing will become weak and thick and rapid because the irregular lump clearly blocks the place of the lung into which it has expanded and extended itself. Often too such conditions constrict the entire chest if women go suddenly into labour or even experience labour subsequently.-Galen, On difficulty in breathing. ${ }^{31}$ 


\section{Conclusion}

Ancient Greek pneuma provided philosophers and physicians with a notion that was central to their understanding of life and vital processes. This 'breath' came to comprise not only the material of respiration but also the vaporous substance supposed to be responsible for the generation of life as such and for vital processes within the body. Because of its refined texture, fluidity, and inherent vitalism, pneuma was also amenable to becoming spirit as distinct from matter and to becoming soul as distinct from body. With the demise of alchemy and the development of empirical science spirit and spirits dropped out of intellectual discourse. But since we continue to wonder how organic life could originate from inorganic matter, may there still be a role for the Greeks' 'congenital breath' if we could gain access to the primordial ooze?

Acknowledgements I am most grateful to Professors Corinne Saunders and Jane Macnaughton for inviting me to participate in 'The Life of Breath' colloquium. The occasion was exceptionally stimulating, and I benefited greatly from all the discussions. I also take this opportunity to thank my classical period copanelists, Dr Phil Horky and Dr Tom Hunt, and our panel's chair, Professor George Boys-Stones.

\section{Notes}

1. For full discussion see R. B. Onians, The Origins of European Thought about the Body, the Mind, the Soul, the World, Time, and Fate (Cambridge: Cambridge University Press, 1951), David B. Claus, Toward the Soul. An Inquiry into the Meaning of Psyche Before Plato (New Haven: Yale University Press, 1981), Michael Clarke, Flesh and Spirit in the Songs of Homer: A Study of Words and Myths (Oxford: Clarendon, 1999), and A. A. Long, Greek Models of Mind and Self (Cambridge, MA: Harvard University Press, 2015).

2. Hermann Diels and Walther Kranz, Die Fragmente der Vorsokratiker (Zürich: Weidmannsche, 1964), 13 B2; G. S. Kirk, J. E. Raven, and M. Schofield, The Presocratic Philosophers (Cambridge: Cambridge University Press, 1983), 160.

3. Diels and Kranz, Fragmente, $22 \mathrm{~B} 12$.

4. Diels and Kranz, Fragmente, 64 B4; Kirk, et al., Presocratic Philosophers, 602 .

5. Diels and Kranz, Fragmente, 64 B5; Kirk, et al., Presocratic Philosophers, 603. 
6. Diels and Kranz, Fragmente, 64 A19; Kirk, et al., Presocratic Philosophers, 612.

7. W. H. S. Jones, Hippocrates, with an English Translation, vol. 2 (Cambridge, MA: Harvard University Press, 1923).

8. For details see Kirk, et al., Presocratic Philosophers, and A. A. Long, ed., The Cambridge Companion to Early Greek Philosophy (Cambridge: Cambridge University Press, 1999).

9. See Horky in this volume.

10. See James Longrigg, Greek Rational Medicine: Philosophy and Medicine from Alcmaeon to the Alexandrians (London: Routledge, 1993).

11. Diels and Kranz, Fragmente, 31 B100, 1-8.

12. W. H. S. Jones, The Medical Writings of Anonymus Londinensis (Cambridge: Cambridge University Press, 1947).

13. Jones, Hippocrates.

14. Plato, Timaeus, trans. by Donald J. Zeyl (Indianapolis: Hackett, 2000).

15. See D. J. Furley and J. S. Wilkie, Galen. On Respiration and the Arteries (Princeton: Princeton University Press, 1984).

16. Empedocles (the T14 author) identified intelligence (noema) with the blood around the heart.

17. See Friedrich Solmsen, 'Greek Philosophy and the Discovery of the Nerves', Museum Helveticum 18 (1961), 150-97.

18. See Long, Greek Models.

19. See Julia Annas, Hellenistic Philosophy of Mind (Berkeley: University of California Press, 1992).

20. On symphyton pneuma in Aristotle see A. L. Peck, ed., Aristotle: Generation of Animals (Cambridge, MA: Harvard University Press, 1943), Martha C. Nussbaum, Aristotle's De Motu Animalium (Princeton: Princeton University Press, 1978), and Gad Freudenthal, Aristotle's Theory of Material Substance: Heat and Pneuma, Form and Soul (Oxford: Clarendon, 1995); on pneuma in Stoicism, see Annas, Hellenistic Philosophy, and in Galen, see The Cambridge Companion to Galen, ed. by R. J. Hankinson (Cambridge: Cambridge University Press, 2008).

21. For reasons of space I omit discussion of Aristotle's account of respiration and its contribution to vital processes: see his work On Respiration in Aristotle on the Soul, Parva Naturalia, On Breath, ed. by W. S. Hett (Cambridge, MA: Harvard University Press, 1936).

22. A. L. Peck, ed., Aristotle: Generation of Animals (Cambridge, MA: Harvard University Press, 1943).

23. This is my translation of the papyrus text of Hierocles which I edited along with Guido Bastianini in Corpus dei Papiri Filosofici Greci e Latini 1.1 (Florence: Olschki, 1992). Hierocles' text was completely unknown before 1900. This particular passage has been barely discussed in print so far and not yet incorporated in standard works on ancient physiology. For 
an accessible version of Hierocles' work, see Hierocles the Stoic: Elements of Ethics, ed. by Ilaria Ramelli (Leiden: Brill, 2011).

24. Stoicism envisioned a four-rank scala naturae in the pneuma that constitutes the world's 'cohesive principle'. All substances, ranging from inanimate bodies to plants, animals (ensouled creatures), and human beings (creatures with rational souls), are held together and activated by the pneuma that constitutes the kind of being that they are.

25. For discussion see Furley and Wilkie, Galen, and Armelle Debru, 'Physiology', in The Cambridge Companion to Galen, 275-78.

26. See Solmsen 'Greek Philosophy'.

27. Furley and Wilkie, Galen.

28. See Pierluigi Donini, 'Psychology', in The Cambridge Companion to Galen, 185.

29. See Julius Rocca, 'Anatomy', in The Cambridge Companion to Galen, 247.

30. I only discovered the existence of this work while I was working on this essay. What put me on to it was a reference by Ben Morison in The Cambridge Companion to Galen, 149, in a discussion of Galen's remarks about language. As far as I have been able to discover, the most recent edition of the work and the only accessible translation of it (into Latin) is that of C. G. Kühn, Galeni Opera Omnia, vol. 7 (Leipzig: Knobloch, 1824). During the Middle Ages the work was translated into Arabic and Syriac, and there are three Latin translations before Kühn's by Niccolo da Reggio, Johannes Vassaeus, and Janus Cornarius. I owe this information to the bibliography of the Corpus Galenicum, ed. by Gerhard Fichtner and Roland Wittwer (Berlin: Berlin-Brandenburgische Akademie der Wissenschaften, 2018).

31. Galeni Opera Omnia, vol. 7, 781-82.

\section{BIBLIOGRAPHY}

Annas, Julia. 1992. Hellenistic Philosophy of Mind. Berkeley: University of California Press.

Beare, John I. 1906. Greek Theories of Elementary Cognition from Alcmaeon to Aristotle. Oxford: Clarendon.

Clarke, Michael. 1999. Flesh and Spirit in the Songs of Homer: A Study of Words and Myths. Oxford: Clarendon.

Claus, David B. 1981. Toward the Soul. An Inquiry into the Meaning of Psyche Before Plato. New Haven: Yale University Press.

Hankinson, R. J., ed. 2008. The Cambridge Companion to Galen. Cambridge: Cambridge University Press.

Long, A. A., ed. 1999. The Cambridge Companion to Early Greek Philosophy. Cambridge: Cambridge University Press. 
2015. Greek Models of Mind and Self. Cambridge, MA: Harvard University Press.

Longrigg, James. 1993. Greek Rational Medicine: Philosophy and Medicine from Alcmaeon to the Alexandrians. London: Routledge.

Nussbaum, Martha C. 1978. Aristotle's De Motu Animalium. Princeton: Princeton University Press.

Onians, R. B. 1951. The Origins of European Thought About the Body, the Mind, the Soul, the World, Time, and Fate. Cambridge: Cambridge University Press.

Solmsen, Friedrich. 1961. Greek Philosophy and the Discovery of the Nerves. Museum Helveticum 18: 150-97

Open Access This chapter is licensed under the terms of the Creative Commons Attribution 4.0 International License (http://creativecommons.org/licenses/ by $/ 4.0 /)$, which permits use, sharing, adaptation, distribution and reproduction in any medium or format, as long as you give appropriate credit to the original author(s) and the source, provide a link to the Creative Commons license and indicate if changes were made.

The images or other third party material in this chapter are included in the chapter's Creative Commons license, unless indicated otherwise in a credit line to the material. If material is not included in the chapter's Creative Commons license and your intended use is not permitted by statutory regulation or exceeds the permitted use, you will need to obtain permission directly from the copyright holder.

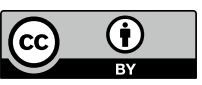

